\title{
FGFR2-related bent bone dysplasia
}

INSERM

\section{Source}

INSERM. (1999). Orphanet: an online rare disease and orphan drug data base. FGFR2related bent bone dysplasia. ORPHA:313855

FGFR2-related bent bone dysplasia is a rare, genetic, lethal, primary bone dysplasia characterized by dysmorphic craniofacial features (low-set, posteriorly rotated ears, hypertelorism, megalophtalmos, flattened and hypoplastic midface, micrognathia), hypomineralization of the calvarium, craniosynostosis, hypoplastic clavicles and pubis, and bent long bones (particularly involving the femora), caused by germline mutations in the FGFR2 gene. Prematurely erupted fetal teeth, osteopenia, hirsutism, clitoromegaly, gingival hyperplasia, and hepatosplenomeg aly with extramedullary hematopoesis may also be associated. 